\title{
Hubungan Kadar Zinc dan Pola Asuh lbu dengan Kejadian Stunting pada Anak Usia 2 - 5 Tahun di Kecamatan Panti Kabupaten Pasaman
}

\author{
Elsa Noftalina ${ }^{1}$, Mayetti $^{2}$, Afriwardi $^{3}$ \\ ${ }^{1}$ Pascasarjana Ilmu Kebidanan Fakultas Kedokteran Universitas Andalas, Padang \\ 2Pediatri, Fakultas Kedokteran Universitas Andalas, Padang \\ ${ }^{3}$ Fisiologi, Fakultas Kedokteran Universitas Andalas, Padang \\ Correspondence email: tocha_140106@yahoo.com
}

\begin{abstract}
Abstrak. Stunting adalah kondisi tubuh yang pendek berdasarkan tinggi badan menurut umur (TB/U) yang standar deviasinya kurang dari -2 dan -3 dari hasil perhitungan $z$-score tabel WHO child growth standard. Stunting merupakan gangguan pertumbuhan irreversibel akibat nutrisi yang tidak memadai dan adanya infeksi berulang selama 1000 hari pertama kehidupan. Indikator dari kurang gizi kronis yang terjadi dalam jangka waktu yang lama sehingga stunting pada anak balita khususnya pada usia 2 - 5 tahun keadaan stunting akan terlihat dengan jelas dan merupakan salah satu indikator status gizi kronis yang dapat memberikan gambaran gangguan secara keseluruhan di masa lampau. Penyebab stunting yaitu kurangnya asupan gizi, penyakit infeksi, pola asuh ibu yang kurang baik, sanitasi lingkungan yang buruk dan rendahnya pelayanan kesehatan. Kekurangan zinc dapat menyebabkan pertumbuhan terganggu dan kekebalan tubuh menurun. Salah satu biomarker yang digunakan yaitu dengan analisis kadar zinc rambut karena dapat menggambarkan kadar zinc kronis pada masa lampau sehingga tepat untuk mengukur kadar zinc pada kondisi stunting yang merupakan kondisi malnutrisi yang sudah berlangsung lama. Desain penelitan case control yang dilakukan di Kecamatan Panti Kabupaten Pasaman dan Laboratorium Kesehatan Daerah Sumatera Barat pada bulan Juni sampai dengan Juli 2019. Sampel penelitian adalah ibu dan anak berusia $2-5$ tahun sebanyak 60 orang dibagi menjadi dua kelompok yaitu anak stunting dan normal diambil secara proportional stratified simple random sampling. Kadar zinc diukur dengan Atomic Absorption Spektrophotometry (AAS) sedangkan pola asuh menggunakan kuesioner. Uji statistik menggunakan uji Mann Whitney dan Chi Square. Hasil penelitian menunjukkan rerata kadar zinc pada anak stunting 154.70 (9-387) $\mu \mathrm{g} / \mathrm{g}$ dan kadar zinc pada anak normal $241.00(60-933) \mu \mathrm{g} / \mathrm{g}$ dengan $p=0.018$, pola asuh makan $(p=0.009)$, pola asuh kebersihan $(p=0.034)$, pola asuh kesehatan $(p=0.017)$, pola asuh stimulasi psikososial $(0.000)$. Kesimpulan penelitian ini adalah terdapat hubungan yang bermakna antara kadar zinc dan pola asuh ibu dengan kejadian stunting.
\end{abstract}

Kata Kunci: Kadar Zinc; Pola Asuh Ibu; Stunting

Abstract. Stunting is a short body condition based on height according to age (TB / U) whose standard deviation is less than -2 and -3 from the Z-score calculation of the WHO child growth standard table. Stunting is an irreversible growth disorder due to inadequate nutrition and recurring infections during the first 1000 days of life. Indicators of chronic malnutrition that occur in a long time so that stunting in children under five, especially at the age of 2-5 years stunting will be clearly visible and is one indicator of chronic nutritional status that can provide an overall picture of the disorder in the past. The causes of stunting are lack of nutrition, infectious diseases, poor parenting, poor environmental sanitation and low health services. Zinc deficiency can cause impaired growth and decreased immunity. One of the biomarkers used is the analysis of hair zinc levels because it can describe chronic zinc levels in the past so it is appropriate to measure zinc levels in the stunting condition which is a long-standing condition of malnutrition. The case control research design was carried out in the Panti District of Pasaman Regency and the West Sumatra Regional Health Laboratory in June to July 2019. The study sample were mothers and children aged 2-5 years as many as 60 people divided into two groups which are stunting and normal children, taken by proportional stratified simple random sampling. Zinc levels were measured by atomic absorption spectrophotometry (AAS) while parenting used questionnaires. Statistical test using Mann Whitney test and Chi Square. The results showed the mean zinc levels in stunting children 154.70 (9-387) $\mu \mathrm{g} / \mathrm{g}$ and zinc levels in normal children $241.00(60-933) \mu g / g$ with $p=0.018$. parental feeding $(p=0.009)$, hygiene parenting ( $p=0.034)$. health care parenting $(p=0.017)$, psychosocial stimulation parenting care $(0,000)$. The conclusion of this study is that there is a significant association between zinc levels and parenting with the incidence of stunting.

Keywords: Mother's Care Practice; Sunting; Zinc Levels

\section{PENDAHULUAN}

Stunting merupakan kondisi kekurangan gizi kronis yang menyebabkan postur tubuh tidak maksimal dan kemampuan kognitif berkurang. Secara global pada tahun 2017 sebanyak 22,2\% atau satu dari empat anakanak usia 0-5 tahun di dunia mengalami stunting. Prevalensi stunting tertinggi sebesar 35\% ditempati oleh Asia Selatan yang kemudian disusul oleh Afrika Timur dan Selatan sebesar $34,1 \%$ dan Afrika Barat dan Tengah sebesar 33,7\% (UNICEF, 2018).

Berdasarkan hasil Riset Kesehatan Dasar (2018), anak usia 24-59 bulan yang mengalami stunting di Indonesia berkisar $30,8 \%$, meskipun terjadi penurunan dari tahun 2013 yaitu $37,2 \%$. Penurunan tersebut masih tetap menjadi masalah kesehatan masyarakat di Indonesia karena dianggap berat bila prevalensi balita pendek sebesar $30-39 \%$ dan serius bila prevalensi pendek $\geq 40 \%$. Sedangkan prevalensi anak usia $0-23$ bulan yang mengalami stunting pada tahun 2018 termasuk dalam kategori sedang yaitu sebesar $29,9 \%$.

Salah satu provinsi yang memiliki prevalensi dengan kategori tinggi yaitu provinsi Sumatera Barat sebesar 30,6 \% (Riskesdas, 2018) dengan kabupaten Pasaman sebagai penyumbang angka kejadian stunting tertinggi pada tahun 2017 yaitu sebanyak 40,6\%. Hal ini yang menjadi alasan Kabupaten Pasaman merupakan salah satu dari 100 Kabupaten/kota prioritas penanganan stunting di Indonesia pada tahun 2018 
yang salah satu wilayahnya adalah di kecamatan Panti dengan prevalensi anak stunting sebesar 53,77\%. (Dinas Kesehatan Kabupaten Pasaman, 2018).

Menurut Nasir (2010) permasalahan gizi, khususnya anak stunting merupakan indikator dari status ekonomi rendah serta indikator dari kurang gizi kronis yang terjadi dalam jangka waktu yang lama sehingga stunting pada anak balita khususnya pada usia $2-5$ tahun akan terlihat dengan jelas dan merupakan salah satu indikator status gizi kronis yang dapat memberikan gambaran gangguan secara keseluruhan di masa lampau. Penelitian Ramli, et al (2009) menyebutkan bahwa prevalensi stunting dan severe stunting lebih tinggi pada anak usia 24 - 59 bulan, yaitu sebesar $50 \%$ dan $24 \%$ dibandingkan anak-anak yang berusia $0-23$ bulan. Tingginya prevalensi stunting pada anak usia 24 - 59 bulan menunjukkan bahwa stunting tidak mungkin reversible.

Faktor penyebab langsung terjadinya stunting adalah penyakit infeksi dan tingkat asupan zat gizi. Kuantitas dan kualitas zat gizi yang terasup di dalam makanan akan sangat menentukan pertumbuhan dan perkembangan balita oleh karena itu makanan harus dapat memenuhi kebutuhan gizi balita (Supariasa, 2012). Faktor lainnya adalah pengetahuan ibu yang kurang, pola asuh yang salah, sanitasi dan hygiene yang buruk dan rendahnya pelayanan kesehatan. Selain itu masyarakat belum menyadari anak pendek merupakan suatu masalah, karena anak pendek di masyarakat terlihat sebagai anak-anak dengan aktivitas yang normal, tidak seperti anak kurus yang harus segera ditanggulangi. Demikian pula halnya gizi ibu saat hamil, masyarakat belum menyadari pentingnya gizi selama kehamilan berkontribusi terhadap keadaan gizi bayi yang akan dilahirkannya kelak (Unicef Indonesia, 2013).

Upaya perbaikan gizi dihadapkan pada masalah gizi makro dan mikro. Salah satunya adalah defisiensi zinc $(\mathrm{Zn})$ yang merupakan masalah gizi mikro yang belum sepenuhnya teratasi, hal ini ditunjukkan dengan angka kejadian defisiensi zinc yang tinggi di Indonesia. Sebesar 17,3\% penduduk di dunia mengalami defisiensi zinc pada tahun 2005, sementara itu $32 \%$ balita Indonesia mengalami defisiensi zinc pada tahun 2006 (Abbas, 2012). Zinc adalah mineral esensial yang memiliki peran penting dalam proses enzimatik, ekspresi gen dan stabilisasi sel. Kekurangan zinc dapat menyebabkan pertumbuhan terganggu dan kekebalan tubuh menurun. (Lindenmayer et al., 2014).

Kadar zinc tubuh dapat diketahui dengan mengunakan biomarker kadar zinc rambut. Analisis rambut sangat penting karena menunjukkan status aktual organisme, status gizi aktual, jumlah disimpan dan akumulasi racun, yang semuanya dapat ditentukan hanya oleh analisis mineral rambut. Analisis rambut memberikan hasil yang tidak bervariasi setiap hari dan tidak mengalami beberapa perubahan seperti darah hitungan, tes darah atau urin (Mutap, 2016). Analisis kadar zinc rambut lebih tepat menggambarkan kadar zinc kronis pada masa lampau sehingga tepat untuk mengukur kadar zinc pada kondisi stunting yang merupakan kondisi malnutrisi yang sudah berlangsung lama.
Penelitian yang dilakukan pada anak stunting dan non stunting di kelurahan Tambak Wedi Kenjeran Surabaya melaporkan bahwa rata-rata kadar zinc rambut pada balita stunting lebih rendah (Oktiva and Adriani, 2017). Rahmawati (2012) juga menyatakan terdapat perbedaan antara kadar zinc rambut berdasarkan derajat stunting dan terdapat korelasi positif antara kadar zinc rambut dengan z-score TB/U. Kadar zinc rambut meningkat dengan meningkatnya z-score $\mathrm{TB} / \mathrm{U}$.

Faktor lain yang dapat mempengaruhi terjadinya stunting pada anak yaitu pola asuh dari ibu maupun keluarga. Pola asuh memiliki peranan yang penting agar terwujudnya pertumbuhan anak yang optimal. Pola asuh adalah penyebab tidak langsung dari kejadian stunting dan apabila tidak dilaksanakan dengan baik dapat menjadi penyebab langsung dari kejadian stunting, artinya pola asuh adalah faktor dominan sebagai penyebab stunting (UNICEF, 2015). Menurut Engle et al (1997) terdapat empat komponen penting didalam pola asuh yang berperan penting yaitu pemberian makanan, kebersihan, kesehatan, dan stimulasi psikososial (Zikria, 2018)

Penelitian yang dilakukan di Kecamatan Lut Tawar, Kabupaten Aceh Tengah ditemukan adanya hubungan antara sosial ekonomi, pola asuh, dan pola makan dengan kejadian stunting. Berdasarkan analisis multivariat, pola asuh adalah faktor paling dominan yang berpengaruh terhadap kejadian stunting di wilayah penelitian tersebut. Subjek penelitian dengan pola asuh yang kurang baik memiliki risiko menjadi stunting 8 kali lebih besar dibandingkan dengan subjek penelitian dengan pola asuh yang baik (Aramico, 2013)

Penelitian yang dilakukan oleh Rahmayana (2014) menunjukkan adanya hubungan yang signifikan dalam pengasuhan ibu terhadap kejadian stunting pada anak usia 24-59 bulan. Hasil yang sama juga ditunjukkan oleh penelitian yang dilakukan oleh Netty (2015) yang menyatakan bahwa pola asuh makan, pola asuh kesehatan dan pola asuh psikososial merupakan faktor risiko yang mempengaruhi kejadian stunting pada anak usia 12-36 bulan diwilayah Puskesmas Sumber Kudus kabupaten Sijunjung.

Berdasarkan uraian diatas menjadi dasar peneliti untuk meneliti hubungan kadar zinc dan pola asuh ibu dengan kejadian stunting pada anak usia 2 - 5 tahun. Tujuan penelitian ini adalah untuk mengetahui hubungan kadar zinc dan pola asuh ibu dengan kejadian stunting pada anak usia 2 - 5 tahun.

\section{METODE PENELITIAN}

Penelitian ini merupakan pemelitian observasional dengan rancangan case control. Populasi penelitian ini adalah ibu dan anak yang berusia $2-5$ tahun di wilayah kerja Puskesmas Pegang Baru dan Puskesmas Kuamang Kecamatan Panti Kabupaten Pasaman. Jumlah sampel penelitian sebanyak 60 orang ( 30 orang anak stunting dan 30 anak normal) yang memenuhi kriteria inklusi dan eksklusi diambil secara proportional stratified simple random sampling. Uji statistik menggunakan Chi Square dan Mann Whitney karena data tidak berdistribusi normal. 


\section{HASIL PENELITIAN}

Pengumpulan data dan sampel telah dilaksanakan mulai bulan Juni sampai dengan Juli 2019 di wilayah kerja Puskesmas Pegang Baru dan Puskesmas Kuamang Kecamatan Panti Kabupaten
Pasaman dan sampel rambut yang terkumpul diperiksa di laboratorium Kesehatan Daerah Sumatera Barat. Pemeriksaan kadar zinc rambut menggunakan Atomic Absorption Spektrophotometry (AAS) sedangkan pengukuran pola asuh menggunakan kuesioner.

Tabel 1. Perbedaan Kadar Zinc Pada Rambut dengan Kejadian Stunting Pada Anak Usia 2 - 5 Tahun di Kecamatan Panti Kabupaten Pasaman

\begin{tabular}{cccc}
\hline Variabel & Anak Stunting & Anak Normal & $P^{*}$ \\
Mean \pm SD (Min - Maks) & Mean \pm SD (Min - Maks) & 0.018 \\
\hline$P^{*}:$ Kadar Zinc & $154.70 \pm 83.167(9-387)$ & $241.00 \pm 187.695(60-933)$ & \\
\hline
\end{tabular}

$P^{*}:$ Mann Whitney Test

Berdasarkan tabel 1 dapat dilihat rerata kadar zinc pada anak stunting lebih rendah dibandingkan anak normal, hasil uji statistik menunjukkan nilai $p<0.05$ yang berarti terdapat perbedaan yang bermakna kadar zinc anak stunting dan normal.
Pola Asuh ibu diukur dalam empat komponen yaitu pola asuh makan, pola asuh kebersihan, pola asuh kesehatan dan pola asuh stimulasi psikososial. Hasilnya dapat dilihat pada tabel 2 .

Tabel 2. Hubungan Pola Asuh Ibu Dengan Kejadian Stunting pada anak usia 2 - 5 Tahun di Kecamatan Panti Kabupaten Pasaman

\begin{tabular}{|c|c|c|c|c|c|c|c|c|c|}
\hline \multirow{3}{*}{ Pola Asuh Ibu } & & \multicolumn{4}{|c|}{ Kejadian Stunting } & & & \multirow{3}{*}{$\begin{array}{c}\text { OR } \\
(95 \% \mathrm{Cl})\end{array}$} & \multirow{3}{*}{$P^{*}$} \\
\hline & & \multicolumn{2}{|c|}{ Stunting } & \multicolumn{2}{|c|}{ Normal } & \multicolumn{2}{|c|}{ Total } & & \\
\hline & & $\mathrm{n}$ & $\%$ & $\mathrm{~N}$ & $\%$ & $\mathrm{~N}$ & $\%$ & & \\
\hline \multirow{2}{*}{ Pola Asuh Makan } & Kurang & 18 & 72.0 & 7 & 23.5 & 25 & 100 & 4.929 & \multirow[b]{2}{*}{0.009} \\
\hline & Baik & 12 & 34,3 & 23 & 65.7 & 35 & 100 & $(1.612-15.071)$ & \\
\hline \multirow{2}{*}{ Pola Asuh Kebersihan } & Kurang & 16 & 69.6 & 7 & 30.4 & 23 & 100 & 3.755 & \multirow[b]{2}{*}{0.034} \\
\hline & Baik & 14 & 37.8 & 23 & 62.2 & 37 & 100 & $(1.239-11.385)$ & \\
\hline \multirow[b]{2}{*}{ Pola Asuh Kesehatan } & Kurang & 12 & 80 & 3 & 20 & 15 & 100 & 6.000 & \multirow{2}{*}{0.017} \\
\hline & Baik & 18 & 40 & 27 & 60 & 45 & 100 & $(1.482-24.299)$ & \\
\hline Pola Asuh Stimulasi & Kurang & 17 & 89.5 & 2 & 10.5 & 19 & 100 & 18.308 & \multirow{2}{*}{0.000} \\
\hline Psikososial & Baik & 13 & 31.7 & 28 & 68.3 & 41 & 100 & (3.674-91.229) & \\
\hline
\end{tabular}

$\overline{P^{*}: \text { Chi Square Test }}$

Tabel 2 menunjukkan bahwa sebagian besar kategori kurang pada pola asuh makan, kebersihan, kesehatan dan stimulasi psikososial dimiliki oleh anak stunting dibandingkan dengan anak normal. Hasil uji analisis statistik juga menunjukkan bahwa terdapat hubungan yang bermakna antara pola asuh makan, pola asuh kebersihan, pola asuh kesehatan serta pola asuh stimulasi psikososial dengan kejadian stunting dimana nilai $p<0,05$.

\section{Pembahasan \\ Kadar Zinc}

Berdasarkan World Health Organization (WHO), United Nations Children's Fund (UNICEF), International Atomic Energy Agency (IAEA), dan International Zinc Nutrition Consultative Group (IZincG) tahun 2017 menyatakan bahwa indikator defisiensi zinc pada populasi salah satunya adalah kejadian stunting pada anak-anak dan asupan seng dibawah kebutuhan individu. Prevalensi stunting dalam populasi apabila mencapai $20 \%$ atau lebih, maka terdapat kemungkinan prevalensi defisiensi zinc juga meningkat. Zinc rambut menggambarkan status zinc dalam jangka lama dan tidak cepat mengalami fluktuasi yang berhubungan dengan asupan makanan dan variasi diurnal.

Pada penilitian ini didapatkan perbedaan yang bermakna kadar zinc antara anak stunting dan anak normal. Hasil penelitian ini selaras dengan yang dilakukan oleh Rahmawati dan Wirawanni (2012) yang menyatakan bahwa terdapat perbedaan yang bermakna secara statistik antara kadar seng rambut dengan derajat stunting $(p=0,010)$ dan terdapat hubungan antara kadar seng rambut dengan status gizi anak berdasarkan $z$-score TB/U $(p=0,022 ; r=0,303)$, hasil tersebut juga menunjukkan korelasi positif dimana anak yang memiliki $z$-score $T B / U$ yang rendah akan cenderung memiliki kadar seng rambut yang rendah.

Diperkuat juga dengan penelitian yang dilakukan oleh Kristiani (2018) yang menyatakan terdapat perbedaan signifikan antara kadar zinc rambut, asupan energi, protein, zinc dan zat besi pada kelompok balita (usia 2459 bulan) stunting dan kelompok non-stunting $(p=0.039)$.

Berbeda dengan penelitian sebelumnya yang dilakukan oleh Susilo (2013) menyatakan bahwa tidak terdapat hubungan antara kadar seng $(\mathrm{Zn})$ rambut dengan $z$-score $\mathrm{PB} / \mathrm{U}$ balita usia $12-24$ bulan $(r=-$ 0,$069 ; p=0,607$ ). Perbedaan hasil penelitian ini dapat terjadi karena perbedaan usia subjek yang diteliti.

\section{Pola Asuh Makan}

Praktik pemberian makan pada balita merupakan landasan yang penting dalam proses pertumbuhan. Di seluruh dunia sekitar $30 \%$ anak dibawah usia lima tahun yang mengalami stunting merupakan konsekuensi dari praktik pemberian makan yang buruk dan infeksi yang terjadi secara berulang (WHO, 2017).

Berdasarkan hasil uji statistik pada tabel 2 menunjukkan bahwa pola asuh makan memiliki nilai $p=$ $0,022(P<0,005)$ dengan OR sebesar 4,929. Hasil ini 
menunjukkan bahwa terdapat hubungan yang signifikan antara pola asuh makan terhadap kejadian stunting pada anak usia 2 - 5 tahun di Kecamatan Panti Kabupaten Pasaman, dimana pola asuh makan yang kurang berisiko meningkatkan kejadian stunting sebanyak 4,929 kali.

Penelitian ini sejalan dengan penelitian yang dilakukan oleh Zikria (2018) yang menunjukkan bahwa terdapat hubungan yang bermakna antara pola asuh makan dengan kejadian stunting pada anak usia 12-35 bulan di wilayah kerja Puskesmas Air Dingin Padang tahun 2018 dimana nilai $p=0,000$

\section{Pola Asuh Kebersihan}

Tabel 2 menunjukkan bahwa terdapat hubungan yang bermakna antara pola asuh kebersihan dengan kejadian stunting dimana nilai $\mathrm{p}=0.034$ dengan $\mathrm{OR}=$ 3,755 . Hasil yang sama juga dimiliki oleh penelitian yang dilakukan Rahmayana et al (2014) di wilayah pesisir Kelurahan Barombong Kecamatan Tamalate Kota Makassar yang menunjukkan bahwa terdapat hubungan signifikan antara pola asuh kebersihan dengan kejadian stunting pada anak usia 24-59 bulan dimana nilai $p<$ $0,05(p=0,000)$.

Sebagian besar ibu tidak mencuci tangan dengan sabun ketika hendak memberi makan anaknya serta tidak membiasakan anaknya untuk mencuci tangan dengan sabun ketika hendak makan bahkan setelah anak selesai Buang Air Besar (BAB). Alasan ibu melakukan hal tersebut karena ibu menganggap tangannya bersih dan menyuapi atau anak makan dengan menggunakan sendok. Kejadian ini bertentangan dengan salah satu fokus kampanye WHO dalam mengurangi timbulnya penyakit-penyakit infeksi seperti diare dengan membiasakan untuk mencuci tangan dengan sabun sebelum makan dan setelah buang air besar karena salah satu penyebab stunting adalah mengalami penyakit infeksi (Kullu et al., 2018). Sebagian besar responden tidak memiliki jamban sendiri. Mereka menggunakan jamban/WC umum bahkan ada beberapa responden yang memiliki kebiasaan BAB di pinggiran sungai. Penelitian Sartika (2010) menunjukkan bahwa keberadaan jamban merupakan faktor yang sangat berpengaruh dan diikuti beberapa faktor lain seperti kebiasaan cuci tangan dan sumber air minum terhadap status gizi Tinggi badan berdasarkan umur (TB/U).

\section{Pola Asuh Kesehatan}

Tabel 2 menunjukkan bahwa terdapat hubungan yang bermakna antara pola asuh kesehatan dengan kejadian stunting pada anak usia 2-5 tahun di Kecamatan Panti Kabupaten Pasaman $(p=0,017$, OR= $6,000)$. Hasil penelitian ini sejalan dengan penelitian yang dilakukan oleh Renyoet et al (2013) di Kecamatan Tallo Kota Makassar yang menunjukkan bahwa terdapat hubungan signifikan antara pola asuh kesehatan dengan kejadian stunting pada anak usia 6-23 bulan dimana nilai $p<0,05(p=0,006)$

Ibu yang memiliki anak stunting jarang membawa anaknya ke Posyandu karena menurut mereka datang ke Posyandu hanya untuk mendapatkan imunisasi saja.
Kebanyakan dari ibu yang datang ke Posyandu juga tidak membawa buku KIA/KMS sehingga tidak memiliki catatan pertumbuhan dan perkembangan anak. Saat Posyandu juga tidak dilakukan pengukuran tinggi badan anak. Pengukuran tinggi badan hanya dilakukan saat ada penimbangan dan pengukuran massal sehingga kejadian stunting terlambat untuk dideteksi. Kehadiran anak ke Posyandu merupakan indikator terjangkaunya pelayanan kesehatan bagi balita karena dengan hadir ke Posyandu balita akan mendapatkan imunisasi, kapsul vitamin $A$, obat cacing dan pengukuran status gizi dengan penimbangan berat badan dan pengukuran tinggi badan (Welasih dan Wirjatmadi, 2012). Beberapa anak stunting juga memiliki riwayat penyakit infeksi seperti TB Paru dan Diare serta imunisasi dasar yang tidak lengkap. Imunisasi mempunyai peran meningkatkan daya tahan tubuh anak terhadap penyakit infeksi. Anak yang tidak mendapatkan imunisasi akan lebih mudah terkena penyakit sehingga dapat mengalami kehilangan nafsu makan dan berakibat terhadap status gizinya (Luciasari, 2011).

\section{Pola Asuh Stimulasi Psikososial}

Berdasarkan tabel 2 diketahui bahwa terdapat hubungan yang signifikan antara pola asuh stimulasi psikososial dengan kejadian stunting pada anak usia 2 5 tahun di Kecamatan Panti Kabupaten Pasaman dengan nilai $P=0,000$ dan pola asuh stimulasi psikosial yang kurang dapat berisiko menyebabkan anak stunting sebanyak 18,308 kali. Hasil penelitian ini sejalan dengan penelitian yang dilakukan oleh Afryanti (2015) di Kecamatan Nanggalo Kota Padang yang menunjukkan bahwa terdapat hubungan signifikan antara pola asuh stimulasi psikososial dengan kejadian stunting pada anak usia 6-23 bulan dimana nilai $p<0,05(p=0,002)$. Hasil penelitian ini tidak sesuai dengan penelitian yang dilakukan oleh Kullu et al (2018) di Desa Wawatu Kecamatan Moramo Utara Kabupaten Konawe Selatan yang menunjukkan tidak adanya hubungan yang signifikan antara rangsangan psikososial dengan kejadian stunting pada anak usia 24-59 bulan dimana nilai $p=0,280$.

Kondisi psikososial yang buruk dapat berpengaruh negatif terhadap penggunaan zat gizi di dalam tubuh, sebaliknya kondisi psikososial yang baik akan merangsang hormon pertumbuhan sekaligus merangsang anak untuk melatih organ-organ perkembangannya. Sesuai dengan teori positive deviance (Zeitlin, 1990) menyatakan bahwa berbagai stimulus yang rutin diberikan oleh ibu atau pengasuh terhadap bayi, baik stimulus visual, verbal dan auditif akan dapat menyebabkan stimulasi growth hormone, metabolisme energy menjadi normal dan imun respon lebih baik (Alauddin, 2012).

\section{SIMPULAN}

Terdapat hubungan yang bermakna antara kadar zinc dan pola asuh ibu dengan kejadian stunting pada anak usia 2 -5 tahun di Kecamatan Panti Kabupaten Pasaman 


\section{DAFTAR PUSTAKA}

Abbas B, Jahari, Arum Atmawikarta, Atmarita, Dini Latief, Drajat, Endang, dkk. (2012). Pedoman Perencanaan Program Gerakan Nasional Sadar Gizi dalam Rangka Seribu Hari Pertama Kehidupan (Gerakan 1000 HPK). Republik Indonesia

Afriyanti, L. (2015). Hubungan Pengetahuan Ibu Tentang Gizi Dan Pola Asuh Dengan Kejadian Stunting Pada Anak Usia 6-24 Bulan Di Wilayah Kerja Puskesmas Nanggalo Kota Padang Tahun 2015. Universitas Andalas. Skripsi

Alauddin. (2012). Gambaran Pola Asuh lbu Anak Balita Gizi Buruk Di Wilayah Kerja Puskesmas Karuwisi Kota Makasar Tahun 2012.UIN Alauddin Makasar.

Aramico, B., T. Sudargo., Dan J. Susilo. (2013). Hubungan Sosial Ekonomi, Pola Asuh, Pola Makan Dengan Stunting Pada Siswa Sekolah Dasar Di Kecamatan Lut Tawar, Kabupaten Aceh Tengah. Jurnal Gizi Dan Dietik Indonesia, 1(3): 121-130

Dinas Kesehatan Kabupaten Pasaman. (2018). Laporan Stunting di wilayah Puskesmas Kabupaten Pasaman. Kabupaten Pasaman

Kullu, V.M., Yasnani., dan H. Lestari. (2018). FaktorFaktor yang Berhubungan dengan Kejadian Stunting pada Balita Usia 24-59 Bulan di Desa Wawatu Kecamatan Moramo Utara Kabupaten Konawe Selatan Tahun 2017. Jurnal IImiah Mahasiswa Kesehatan Masyarakat, Vol. 3 (2): 1 11

Luciasari. (2011). Faktor - faktor Penyimpangan Positif Status Gizi Balita. Badan Litbang Kesehatan, vol 34 No. 2,2011

Lindenmayer et al. Lindenmayer Gw, Stoltzfus Rj, Pendergast Aj. (2014). Interaction Between Zinc Deficiency And Enviromental Enterophaty In Developing Countries. American Society Of Nutrition

Mutap A, Huremovic J, Nuhanovic M. (2016). Analysis of Some metals in Human Hair by the AAS Method. Bulletin of the Chemists and Technologists of Bosnia and herzegovina. 2016;46:19-26

Nasir, M. (2010) Rahasia Kecerdasan Anak Memaksimalkan Perkembangan Otak. Jakarta: PT. Kompas Media Nusantara.

Netty, R. (2015). Hubungan Pola Asuh Dengan Kejadian Stunting Pada Anak Umur 12 - 36 Bulan di Wilayah Puskesmas Sumpur Kudus Kabupaten Sijunjung. Tesis. Padang: Universitas Andalas

Oktiva dan Adriani. (2017). Perbedaan Kadar Zinc Rambut Pada Anak Stunting Dan Non Stunting Usia 12-24 Bulan Di Kelurahan Tambak Wedi Kenjeran Surabaya. Amerta Nutr: 133-142

Rahmawati, A dan Wirawanni, Y. (2012). Perbedaan Kadar Seng (Zn) Rambut Berdasarkan Derajat Stunting Pada Anak Usia 6-9 Tahun. Journal of Nutrition College, Volume 1, Nomor 1, Tahun 2012, Halaman 365-372.

Rahmayana, A. (2014). Hubungan Pola Asuh lbu Dengan Kejadian Stunting Anak Usia 24-59 Bulan Di Posyandu Asoka di Wilayah Pesisir Kelurahan
Barombong Kecamatan Tamalate Kota Makassar Tahun 2014. Public Health Science Journal, (Vi)2: 424-436

Ramli, Agho, K. E., Inder, K. J., Bowe, S. J., Jacobs, J., dan Dibley, M. J. (2009). Prevalence and risk factors for stunting and severe stunting among underfives in North Maluku province of Indonesia. Jurnal BMC Pediatrics 2009, 9: 64. Maluku: BMC Pediatrics

Renyoet, B.S., V. Hadju., dan St.N. Rochimiwati. 2013. Hubungan Pola Asuh Dengan Kejadian Stunting Anak Usia 6-23 Bulan Di Wilayah Pesisir Kecamatan Tallo Kota Makassar. Universitas Hasanuddin Makassar. Skripsi

Riset Kesehatan Dasar. (2018). Hasil Utama RISKEDAS 2018. Kementerian Kesehatan Badan penelitian dan Pengembangan Kesehatan.

Sartika, R. (2010). An Anlysis on the Usage of Health Service Related to Nutritional Status of Under Five Years Old Children. J Kesehatan Masyarakat Nasional, 2010; 5 (2)

Supariasa, I.D.N. (2012). Pendidikan Dan Konsultasi Gizi. EGC: Jakarta

Unicef Indonesia, (2013). Ringkasan Kajian Gizi Ibu Dan Anak, Oktober 2012. Www.Unicef.Org Diakses tanggal 16 Maret 2019

Unicef. (2015). Improving Child Nutrition The Achievable Imperative For Global Progress.Diakses:Www.Unicef.Org/Media/Files/N utrition_Report_2013. Tanggal 16 Maret 2019

UNICEF. (2018). Malnutrition. Tersedia Di: Http://Data.Unicef.Org/Topic/Nutrition/ Alnutrition Vol. XIX, Suplemen. Diakses Tanggal 16 Maret 2019

Welasih B.dan Wirjatmadi R. ( 2012). Beberapa Faktor yang Berhubngan Dengan Status Gizi Balita Stunting. The Indonesian Journal Of Public Health, Vol. 8. No. 3 Maret 2012., 99-104

World Health Organization (WHO). (2017). Levels and Trends in Child Malnutrition. http;//www.who.int/nutgrwthdb/jme.unicef.who.wb. pdf. diakses Tanggal 16 Maret 2019

Zikria, (2018). Hubungan Pola Asuh Ibu Dengan Kejadian Stunting Pada Anak Usia 12-35 Bulan Di Wilayah Kerja Puskesmas Air Dingin Padang Tahun 2018. Universitas Andalas 